\title{
Radon Levels in a Hospital in Niterói Municipality-RJ, Brazil
}

\author{
Camila R. Silva, ${ }^{*, a}$ Pedro P. Caldeira, ${ }^{a}$ Angela S. F. Nani ${ }^{b}$ and Emmanoel V. Silva-Filho ${ }^{a}$ \\ a Programa de Pós-Graduação em Geoquímica, Universidade Federal Fluminense, \\ Outeiro São João Batista, s/n, 24020-141 Niterói-RJ, Brazil \\ ${ }^{b}$ Departamento de Medicina Clínica, Hospital Universitário Antônio Pedro, \\ Universidade Federal Fluminense, Rua Marquês de Paraná, 303, 24033-900 Niterói-RJ, Brazil
}

\begin{abstract}
Uranium and radium are present in soil, rocks, water and building materials, therefore the presence of ${ }^{222} \mathrm{Rn}$ in the air is natural, and its concentration is determined mainly by physical factors such as soil cover, altitude, porosity and soil particle size, and meteorological conditions. In rooms with poor ventilation, ${ }^{222} \mathrm{Rn}$ can accumulate to high concentrations, which increases the risk of developing lung cancer due to continuous exposure to this gas. In this work, ${ }^{222} \mathrm{Rn}$ was monitored, with the aid of a real-time radon monitor, RAD7, in offices and rooms at Hospital Universitário Antônio Pedro in order to evaluate the levels of ${ }^{222} \mathrm{Rn}$ to which people are exposed. In general, the values measured in this work are similar to values observed in other studies around the world. The obtained ${ }^{222} \mathrm{Rn}$ level of $40 \mathrm{~Bq} \mathrm{~m}^{-3}$ is close to the world average of $37 \mathrm{~Bq} \mathrm{~m}^{-3}$ defined by the United States Environmental Protection Agency (US EPA).
\end{abstract}

Keywords: radon, ionizing radiation, radio-induced cancer, RAD7

\section{Introduction}

The aging of the world population as a consequence of increased life expectancy permits chronic-degenerative diseases, such as cancer, in the epidemiological setting and as a public health problem. ${ }^{1}$ Lung cancer, one of the most common of all malign tumors, is mostly associated with smoking, ${ }^{2}$ however, exposure to ${ }^{222} \mathrm{Rn}$ also represents a significant risk factor. ${ }^{3}$

${ }^{222} \mathrm{Rn}$ is a natural radioactive noble gas. It is estimated that its abundance in Earth's atmosphere is about one part in $10^{21}$ (one part per sextillion). ${ }^{4}$ It is one of the gases with higher density $\left(1.217 \mathrm{~g} \mathrm{~L}^{-1}\right)$, being about eight times the density of the air. It has three radioactive isotopes: radon $\left({ }^{222} \mathrm{Rn}\right)$, half-life of 3.82 days; thoron $\left({ }^{220} \mathrm{Rn}\right)$, half-life of $55.6 \mathrm{~s}$; and actinon $\left({ }^{219} \mathrm{Rn}\right)$, half-life of $3.96 \mathrm{~s}$, which are formed by the decay of radium-226 $\left({ }^{226} \mathrm{Ra}\right)$, radium-224 $\left({ }^{224} \mathrm{Ra}\right)$ and radium-223 $\left({ }^{223} \mathrm{Ra}\right)$, respectively. They all disintegrate by emitting alpha particles, producing polonium isotopes, which in turn decay by emitting alpha particles to originate the stable isotopes of lead.

Such isotopes are the major contributors to human exposure to natural radiations. ${ }^{3}$ The typical concentration of

*e-mail: r.s.camila@hotmail.com
${ }^{222} \mathrm{Rn}$ in the soil varies from 4 to $40 \mathrm{kBq} \mathrm{m}^{-3}$, considerably higher than that found in the atmosphere. ${ }^{5}$ Because it is a gas, it presents high mobility, facilitating its dispersion to the terrestrial surface through the diffusion or convective currents through pores and fissures in the ground and by groundwater. ${ }^{6}$ Outdoors, where it is diluted at low concentrations, it represents a significantly lower risk than inside buildings, where it can accumulate to high levels. The magnitude of the indoor ${ }^{222} \mathrm{Rn}$ concentration depends mainly on the building material used, the composition of the soil under and around the building, degree of ventilation of closed environments, and meteorological parameters, such as humidity, precipitation, atmospheric pressure and temperature. ${ }^{6,7}$

Recent studies have reported the risk of inhalation of ${ }^{222} \mathrm{Rn}$ to human health, since its decay products ( $\operatorname{solid}^{218} \mathrm{Po}$ and ${ }^{214} \mathrm{Po}$ ) lodge in the lungs where they can radiate and penetrate membranous cells, bronchi and other lung tissues. The lung cells can still undergo oxidative stress, inducing carcinogenesis. ${ }^{8}$ The alpha particles released during the decay of the ${ }^{222} \mathrm{Rn}$ pass through the cytoplasm generating superoxide anions $\left(\mathrm{O}_{2}^{-}\right)$and hydrogen peroxide $\left(\mathrm{H}_{2} \mathrm{O}_{2}\right)$ in the intracellular environment that produces mutations and other lesions in the deoxyribonucleic acid (DNA). ${ }^{9}$ By means of the "viewer effect", the cells affected by radiation 
can induce oxidative stress in adjacent non-irradiated cells. Researches have shown that with prolonged exposure and at low doses there is a larger hazard to human health than short-term exposures, even at high doses..$^{10,11}$ Oni et al. ${ }^{12}$ emphasized the importance of monitoring and development of mitigating measures for closed environments that allow the accumulation of this gas, such as schools, offices, residences, hospitals.

Currently, the annual effective dose due to indoor ${ }^{222} \mathrm{Rn}$ is $10 \mathrm{mSv} \mathrm{y}^{-1}$, which corresponds to the concentration of ${ }^{222} \mathrm{Rn}$ in the air of $300 \mathrm{~Bq} \mathrm{~m}^{-3}$. However, it is recommended that indoor concentrations do not exceed $100 \mathrm{~Bq} \mathrm{~m}^{-3} \cdot{ }^{13-15}$

Considering the reasons given, this study aims to measure and discuss the levels of indoor ${ }^{222} \mathrm{Rn}$ present in different rooms of the Hospital Universitário Antônio Pedro (HUAP), the largest health facility in the city of Niterói, in addition to compare the concentrations found with the established limits by international regulatory agencies.

\section{Experimental}

\section{Study area}

The study was carried out in seven rooms of the HUAP, located in the city of Niterói, Rio de Janeiro. HUAP is one of the largest and most complex health units in the city of Niterói, being considered in the hierarchy of the Brazilian Unified Health System (Sistema Único de Saúde, SUS) as a tertiary and quaternary level hospital, that is, it presents a high complexity of treatment. Its area of coverage reaches an estimated population of more than two million inhabitants. ${ }^{16}$

The hospital facilities are distributed in eight floors, however, for this study only three (second, fourth, and sixth) floors have been selected. These environments had a moderate frequency of use by the employees, maximum $8 \mathrm{~h}$ a day, during the week, and remained closed for most of the study period, allowing the analysis of the gas behavior in the environment.

\section{Instrumental analysis and sampling}

Indoor ${ }^{222} \mathrm{Rn}$ concentration in hospital rooms was determined using a Durridge RAD7 solid-state radon detector (Figure 1). The measurement time was $72 \mathrm{~h}$, following an adaptation of the methodology proposed by Tung et al. ${ }^{18}$ However, instead of measuring outdoor ${ }^{222} \mathrm{Rn}$, the background of the study area was simulated with analysis in a container laboratory. This environment was chosen since the container is made of materials with low ${ }^{226} \mathrm{Ra}$ content, as shown in Table 1.

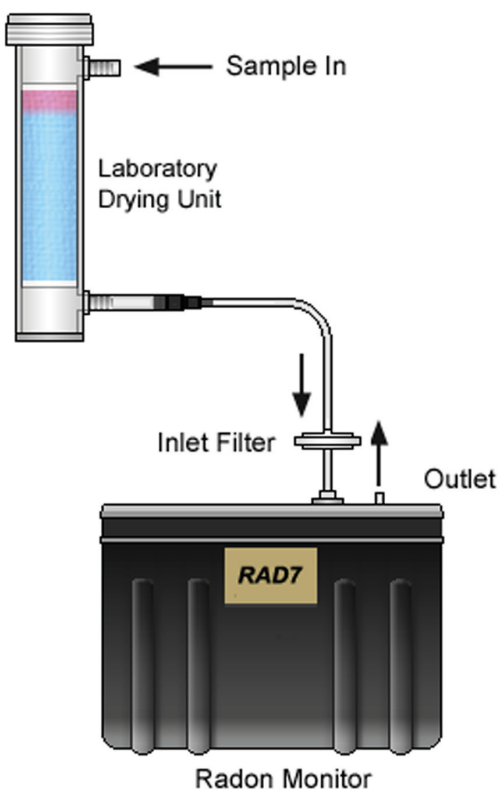

Figure 1. Schematic representation of RAD7 equipment used in ${ }^{222} \mathrm{Rn}$ monitoring (adapted from RAD7 manual, ${ }^{17}$ p. 14).

Table 1. Description of the studied rooms

\begin{tabular}{|c|c|c|c|}
\hline Room & Floor & $\begin{array}{l}\text { Approximate room } \\
\text { volume } / \mathrm{m}^{3}\end{array}$ & Building and covering material of rooms \\
\hline Container laboratory & ground floor & 30.0 & steel sheet walls covered with PVC lining; wood floor \\
\hline Respiratory physiopathology unit & second & 37.0 & walls and concrete floor; walls and ceiling coated with paint \\
\hline Cardio-oncology unit & second & 36.0 & walls and concrete floor; walls and ceiling coated with paint \\
\hline Hemodynamics sector (rest room) & second & 46.0 & $\begin{array}{l}\text { concrete walls, coated with paint; drywall ceiling; floor covered } \\
\text { by ceramics }\end{array}$ \\
\hline Clinical pathology laboratory (CPL) & fourth & 38.0 & walls and concrete floor; walls and ceiling coated with paint \\
\hline Immunopathology laboratory & fourth & 95.0 & walls and concrete floor; walls and ceiling coated with paint \\
\hline Department of clinical medicine & sixth & 28.0 & walls and concrete floor; walls and ceiling coated with paint \\
\hline Department of cardiology & sixth & 36.0 & walls and concrete floor; walls and ceiling coated with paint \\
\hline
\end{tabular}

PVC: polyvinyl chloride. 
The equipment was placed approximately $1.5 \mathrm{~m}$ from the ground, being away from walls, windows and doors, minimizing possible interference by the air circulation. Before each measurement, 10 min of purging was performed to remove possible remnants of radon and its daughter nuclides from the analysis chamber.

Due to the high air humidity of the study region, an average of $76 \%,{ }^{19}$ it was required the use of drierite, a desiccant agent, in order to maintain this parameter lower than $10 \%$, maximizing the equipment efficiency. However, some measurements required the use of an automatic correction through the Capture software, ${ }^{20}$ which adapts the results to a lower humidity condition.

In this study, nine measurements were performed in seven different environments (second, fourth and sixth floors) from the HUAP, from May to August 2016, as listed in Table 1. Air conditioners were in use in all rooms monitored with the exception of the respiratory physiopathology unit and cardio-oncology, which can reduce the levels of ${ }^{222} \mathrm{Rn}$ and its daughter nuclides in these rooms. ${ }^{21}$ Rooms were maintained closed, or with limited access during the measurements period, in order to minimize interference from the external environment.

\section{Results and Discussion}

The minimum, maximum and the average concentrations obtained are shown in Table 2.
The rest room, located in the newly constructed section of the HUAP, was built using different construction and structuring materials from the other rooms studied. For example, it has a low ceiling in comparison to the high ceiling seen in the other rooms and it is lined with phosphogypsum, which is widely used as a building material, replacing the natural gypsum.

It is known that phosphogypsum may contain impurities, such as uranium, thorium and radium, that can increase the natural radioactivity. ${ }^{22,23}$ Studies about radiochemical characterization of Brazilian phosphogypsum has shown the ${ }^{226} \mathrm{Ra}$ content on this material can vary between 22 to $695 \mathrm{~Bq} \mathrm{~kg}^{-1} .24,25$ Although radium measurements on phosphogypsum were not performed in this study, it is possible to estimate, based on results found in other studies, that the indoor ${ }^{222} \mathrm{Rn}$ levels measured, above the hospital average, were influenced by radium presence in the building material used.

In order to confirm the values found, two more measurements were performed in the rest room, with different durations and on different days of the week, as can be seen in Table 3 .

It is observed, according to Table 2, that as the pavement changes, there is a tendency to decrease the concentrations found, corroborating the observation made by the United States Environmental Protection Agency (US EPA), ${ }^{11}$ where concentrations of this gas would be higher in the basement and first floor.

Table 2. Average, minimum and maximum concentrations of indoor ${ }^{222} \mathrm{Rn}$

\begin{tabular}{lccc}
\hline Hospital room & Minimum concentration $/\left(\mathrm{Bq} \mathrm{m}^{-3}\right)$ & Average concentration / $\left(\mathrm{Bq} \mathrm{m}^{-3}\right)$ & Maximum concentration / $\left(\mathrm{Bq} \mathrm{m}^{-3}\right)$ \\
\hline Background & 0.1 & 2.5 & 4.7 \\
Respiratory physiopathology unit & 6.0 & 11.8 & 21.2 \\
Cardio-oncology unit & 3.0 & 10.6 & 15.6 \\
Hemodynamics sector (rest room) & 14.8 & 39.3 & 67.9 \\
Immunopathology laboratory & 5.0 & 11.2 & 32.9 \\
Clinical pathology laboratory (CPL) & 1.0 & 3.8 & 8.5 \\
Department of clinical medicine & 4.4 & 9.7 & 17.6 \\
Department of cardiology & 2.3 & 9.5 & 17.6 \\
\hline
\end{tabular}

Table 3. Triplicate determination of ${ }^{222} \mathrm{Rn}$ concentration in the rest room

\begin{tabular}{lcccc}
\hline Date & $\begin{array}{c}\text { Measurement } \\
\text { time / } \mathrm{h}\end{array}$ & $\begin{array}{c}\text { Minimum concentration / } \\
\left(\mathrm{Bq} \mathrm{m}^{-3}\right)\end{array}$ & $\begin{array}{c}\text { Average concentration / } \\
\left(\mathrm{Bq} \mathrm{m}^{-3}\right)\end{array}$ & $\begin{array}{c}\text { Maximum concentration / } \\
\left.(\mathrm{Bq} \mathrm{m})^{-3}\right)\end{array}$ \\
\hline 06 June to 07 June & 26.4 & 11.2 & 34.5 & 60.7 \\
17 June to 20 June & 74.1 & 19.6 & 47.6 & 77.1 \\
04 August to 05 August & 34.0 & 13.5 & 35.4 & 65.8 \\
Standard deviation & - & 3.5 & 5.9 & 6.8 \\
RSD / \% & - & 24.0 & 14.9 & 10.1 \\
\hline
\end{tabular}

RSD: relative standard deviation. 
Besides the types of building materials used, the climatic parameters also influence the accumulation of indoor ${ }^{222} \mathrm{Rn}$ in rooms with low ventilation. ${ }^{7,22,26}$ Analyzing the meteorological parameters that can influence the levels of indoor ${ }^{222} \mathrm{Rn}$ found, it is noticed that during the measurement months there were abrupt fluctuations of temperature (differences of up to $17{ }^{\circ} \mathrm{C}$ ), rainfall and relative humidity of the air. These data were obtained from the Brazilian National Institute of Meteorology (Instituto Nacional de Meteorologia, INMET $)^{19}$ and are presented in Figure 2, in which the behavior of the gas accumulation in the rooms studied as a function of the meteorological conditions is presented.

Due to the low precipitation on the sampling days, it was not possible to determine a relationship between this parameter and the indoor ${ }^{222} \mathrm{Rn}$ concentration. The
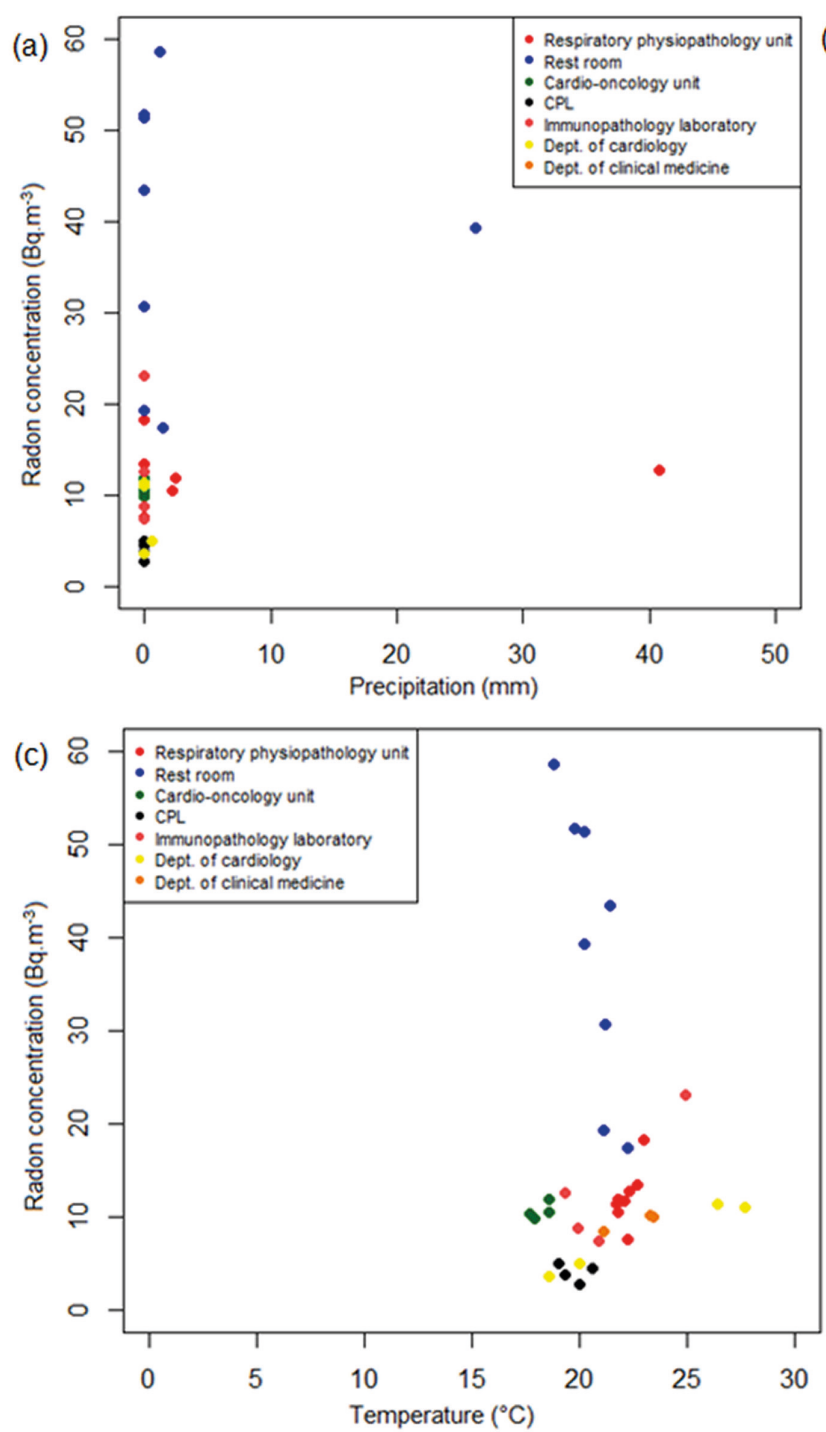

data indicate that, in general, an increase in rainfall and, consequently, humidity has the effect of decreasing the concentration of ${ }^{222} \mathrm{Rn}$, as can be seen on the respiratory physiopathology unit, where an increase of rainfall caused a decrease in $30 \%$ of indoor ${ }^{222} \mathrm{Rn}$. However, a significant linear correlation was not observed between indoor ${ }^{222} \mathrm{Rn}$ levels and meteorological conditions, therefore a detailed analysis was not possible.

The International Commission on Radiological Protection (ICRP) and the World Health Organization (WHO) recommend that concentrations of ${ }^{222} \mathrm{Rn}$ in residences should be less than $100 \mathrm{~Bq} \mathrm{~m}^{-3}$, not exceeding the maximum limit of $300 \mathrm{~Bq} \mathrm{~m}^{-3}$, and in workplaces, where the occupancy time is around $2000 \mathrm{~h}$ per year, such limits are in the range of 500 and $1500 \mathrm{~Bq} \mathrm{~m}^{-3}$, which corresponds to an effective annual dose range of 3 to $10 \mathrm{mSv}^{27}$
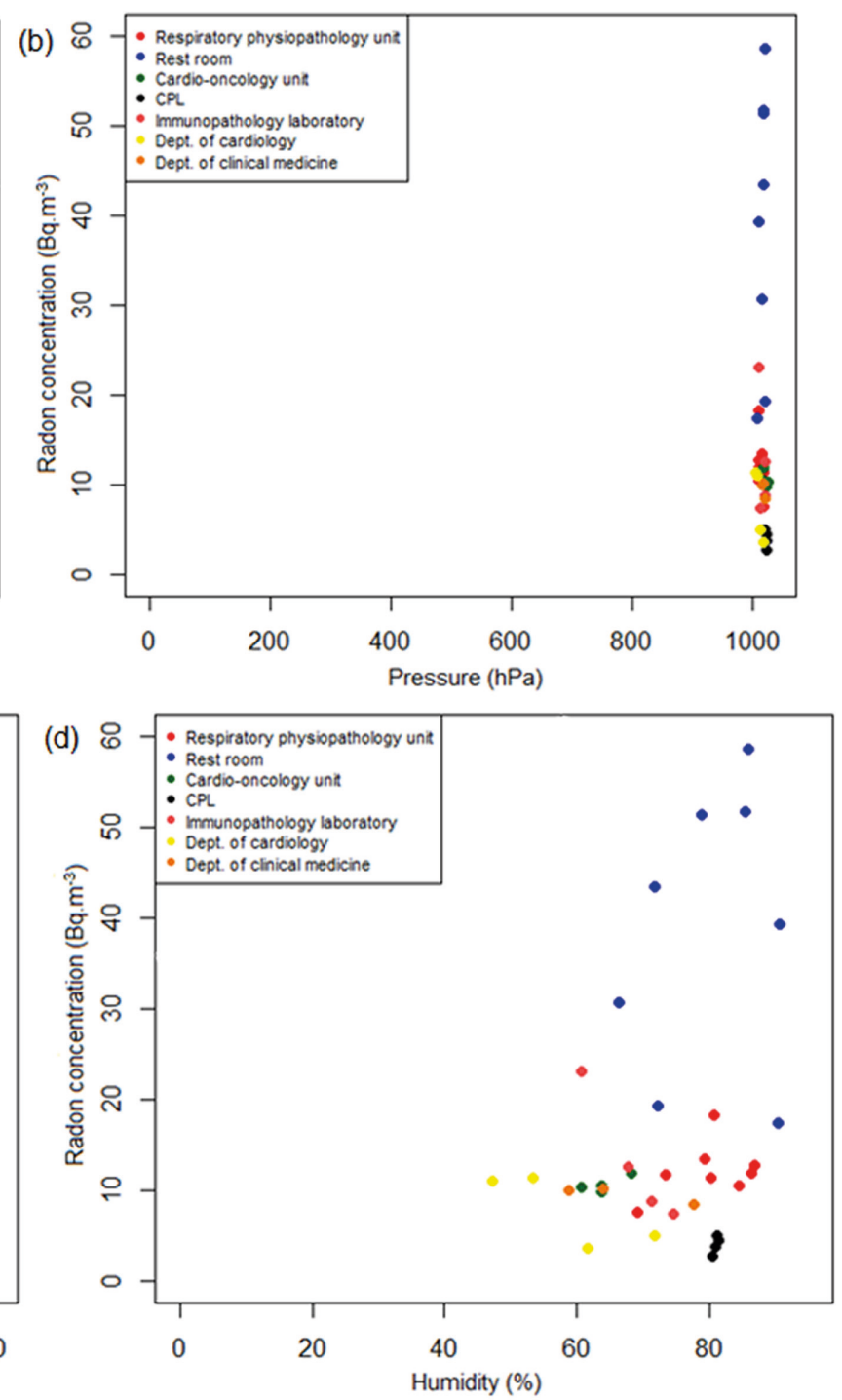

Figure 2. Variation of ${ }^{222} \mathrm{Rn}$ concentration measured in HUAP rooms between May and August 2016, depending on the meteorological conditions presented on measurement days. (a) Variation between ${ }^{222} \mathrm{Rn}$ and precipitation; (b) variation between ${ }^{222} \mathrm{Rn}$ and pressure; (c) variation between ${ }^{222} \mathrm{Rn}$ and temperature; and (d) variation between ${ }^{222} \mathrm{Rn}$ and humidity. 
Table 4. Comparison of the concentrations of ${ }^{222} \mathrm{Rn}$ found in the literature with those obtained in this study

\begin{tabular}{lcc}
\hline Study area & Country & ${ }^{222}$ Rn level $/\left(\mathrm{Bq} \mathrm{m}{ }^{-3}\right)$ \\
\hline HUAP & Brazil & 3.8 to 47.6 \\
Residences in Baixada Santista & Brazil & 56.0 to 168.0 \\
Residences in Natal & Brazil & 5.0 to 160.0 \\
Residences in Poços de Caldas & Brazil & 16 to 1645 \\
Residences in Rio de Janeiro & Brazil & $<5$ to 200 \\
\hline
\end{tabular}

HUAP: Hospital Universitário Antônio Pedro.

The concentrations of ${ }^{222} \mathrm{Rn}$ in the offices and rooms studied are below the maximum limit recommended by both the ICRP and WHO, and the values obtained are similar to the results found in other studies in the country, as can be observed in Table 4. Thus, mitigative measures are not required. However, it is recommended that there be subsequent studies and periodic monitoring of these sites, in particular the room in the hemodynamics sector, in order to ensure that the levels of indoor ${ }^{222} \mathrm{Rn}$ do not exceed the established limits.

\section{Conclusions}

Records and data on the effects of inhalation of indoor ${ }^{222} \mathrm{Rn}$ for human health are more recurrent in countries with cold weather, where there is a decrease in the ventilation in the winter that is propitious for the accumulation of gas. And in countries with a tropical weather, such as Brazil, studies about the risks of ${ }^{222} \mathrm{Rn}$ accumulation and its relation to human health, are often incipient, especially those that investigate the association of climatic parameters and radon concentration in poor ventilation environments. Locations as hospitals, where a restricted air circulation offers a potential health risk due to increase of indoor ${ }^{222} \mathrm{Rn}$, should be better investigated.

The concentrations found were all below the limit established by the WHO, of $100 \mathrm{~Bq} \mathrm{~m}^{-3}$, therefore, not needing mitigating actions. However, the rest room of the hemodynamics sector requires attention since it presented high levels of this gas and a possibility to exceed the levels considered as safe in an analysis with longer study time.

\section{Acknowledgments}

The authors are thankful to Tarcisio Rivello, general superintendent of Hospital Universitário Antônio Pedro and to CAPES for providing the financial support to carry out this work.

\section{References}

1. Antoniazzi, B. N.; Silva, N. C.; Cunha, T. N.; Otero, U. B.; Projeto Planalto Poços de Caldas - Pesquisa Câncer e Radiação Natural - Incidência e Comportamento de Risco; Secretaria de Estado de Saúde de Minas Gerais: Belo Horizonte, 2013.

2. http://www2.inca.gov.br/wps/wcm/connect/tiposdecancer/site/ home/pulmao, accessed in July 2018.

3. https://www.epa.gov/radon/physicians-guide-radon, accessed in July 2018.

4. Afonso, J. C.; Quim. Nova Esc. 2009, 32, 267.

5. National Research Council; Evaluation of Guidelines for Exposures to Technologically Enhanced Naturally Occurring Radioactive Materials; The National Academies Press: Washington, DC, 1999.

6. Sharma, N.; Virk, H. S.; Radiat. Meas. 2001, 34, 467.

7. Xie, D.; Liao, M.; Kearfott, K. J.; Radiat. Meas. 2015, 82, 52.

8. Narayanan, P. K.; Goodwin, E. H.; Lehnert, B. E.; Cancer Res. 1997, 57, 3963.

9. Bonner, M. R.; Bennet, W. P.; Xiong, W.; Lan, Q.; Brownson, R. C.; Harris, C. C.; Field, R. W.; Lubin, J. H.; Alavanja, M. C. R.; Int. J. Cancer 2006, 119, 1462.

10. Yngveson, A.; Williams, C.; Hjerpe, A.; Lundeberg, J.; Söderkvist, P.; Pershagen, G.; Cancer Epidemiol., Biomarkers Prev. 1999, 8, 433.

11. United States Environmental Protection Agency (US EPA); EPA Assessment of Risks from Radon in Homes, EPA 402-R-03-003; Office of Radiation and Indoor Air: Washington, DC, 2003.

12. Oni, O. M.; Isola, G. A.; Oladapo, O. O.; Oni, E. A.; Environ. Earth Sci. 2012, 4, 131.

13. Comissão Nacional de Energia Nuclear (CNEN); Níveis de Intervenção e de Ação para Exposição Crônica, Posição Regulatória 3.01/007. Available at http://appasp.cnen.gov.br/ seguranca/normas/pdf/pr301_07.pdf, accessed in July 2018.

14. International Commission on Radiological Protection (ICRP); 1990 Recommendations of the International Commission on Radiological Protection, Publication 60; Pergamon Press: New York, 1991.

15. World Health Organization (WHO); WHO Handbook on Indoor Radon: a Public Health Perspective; WHO Press: Geneva, 2009. 
16. http://www.ebserh.gov.br/web/huap-uff/historia, accessed in July 2018.

17. https://www.durridge.com/documentation/RAD7\%20Manual. pdf, accessed in July 2018.

18. Tung, T. C. W.; Niu, J. L.; Burnett, J.; Lau, J. O. W.; Radiat. Meas. 2004, 40, 110.

19. http://www.inmet.gov.br/sonabra/pg_dspDadosCodigo_sim. php?QTY1Mg==, accessed in July 2018.

20. Durridge Company, Inc.; CAPTURE RAD7 Data Acquisition and Analysis; Durridge Company, Inc., Billerica, 2017.

21. Marley, F.; Denman, R.; Phillips, P. S.; Radiat. Prot. Dosim. 1998, 76, 273.

22. Rutherford, P. M.; Dudas, M. J.; Samek, R. A.; Sci. Total Environ.1993, 149, 1.

23. United Nations Scientific Committee on the Effects of Atomic Radiation (UNSCEAR); Sources, Effects and Risks of Ionizing Radiation, UNSCEAR 2016 Report; United Nations: New York, 2017.
24. Mazzilli, B.; Palmirom, V.; Saueia, C.; Nisti, M. B.; J. Environ. Radioact. 2000, 49, 113.

25. Borges, R. C.; Ribeiro, F. C. A.; Lauia, D. C.; Bernardo, A. V. B.; J. Environ. Radioact. 2013, 126, 188.

26. Kullab, M.; Appl. Radiat. Isot. 2005, 62, 765.

27. Minkin, L.; Shapovalov, A. S.; Sci. Total Environ. 2016, 565, 1.

28. Geraldo, L. P.; Santos, W.; Marques, A. L.; Botari, A.; Radiol. Bras. 2005, 38, 283.

29. Marcon, A. E.; Navoni, J. A.; Galvão, M. F. O.; Garcia, A. C. F. S.; Amaral, V. S.; Petta, R. A.; Campos, T. F. C.; Panosso, R.; Quinelato, A. L.; Medeiros, S. R. B.; Chemosphere 2017, 167,36 .

30. Magalhães, M. H.; Amaral, E. C. S.; Sachett, I.; Rochedo, E. R. R.; J. Environ. Radioact. 2003, 67, 131.

Submitted: May 11, 2018

Published online: July 17, 2018 